\title{
Prophylactic use of acetazolamide to prevent intraocular pressure elevation following Nd-YAG laser posterior capsulotomy
}

\author{
Ioannis D Ladas, George P Pavlopoulos, Stefanos N Kokolakis, George P Theodossiadis
}

\begin{abstract}
Fifty four eyes of 54 patients undergoing Nd-YAG laser posterior capsulotomy were randomly assigned to pretreatment with either $125 \mathrm{mg}$ of oral acetazolamide (group A) or placebo (group B). During the first 3 hours following capsulotomy, an intraocular pressure (IOP) rise of at least $10 \mathrm{~mm} \mathrm{Hg}$ was recorded in eight of the 26 eyes of group B $(30.8 \%)$ and in none of the 28 eyes of group $A$ $(p<0.01)$. A rise of at least $5 \mathrm{~mm} \mathrm{Hg}$ was recorded in $16 / 26(61.5 \%)$ and $4 / 28(14.3 \%)$ eyes respectively $(p<0.001)$. Three eyes of group B developed an IOP greater than $35 \mathrm{~mm}$ Hg. We found that pretreatment with a low dose of acetazolamide is highly effective in preventing IOP elevation following Nd-YAG laser posterior capsulotomy.

(Br f Ophthalmol 1993; 77: 136-138)
\end{abstract}

Intraocular pressure (IOP) elevation is a very frequent complication of neodymium-YAG $(\mathrm{Nd}$ YAG) laser posterior capsulotomy..$^{1-10}$ Although this IOP elevation, which characteristically reaches a peak within the first 3 postoperative hours, usually resolves without sequelae, it may lead to visual field loss and/or loss of central vision, particularly in eyes with pre-existing glaucomatous damage..$^{40-12}$

Various topical ocular hypotensive agents have been used prophylactically in an attempt to prevent the postlaser IOP rise. Pretreatment with topical $1 \%$ apraclonidine $e^{13-15}$ or $0.5 \%$ levobunolol ${ }^{16}$ proved very effective, while topical $0.5 \%$ timolol maleate ${ }^{17-19}$ or $4 \%$ pilocarpine $^{1920}$ provided only partial protection.

We designed this prospective, randomised, double-masked study to evaluate whether oral acetazolamide given in a very low dose is effective prophylaxis for the IOP rise following routine $\mathrm{Nd}-\mathrm{YAG}$ laser posterior capsulotomy.

Subjects and methods

Fifty four eyes of 54 patients undergoing $\mathrm{Nd}$ YAG laser posterior capsulotomy because of posterior capsule opacification after extracapsular cataract extraction and implantation of posterior chamber intraocular lens were prospectively selected. In every case, the posterior capsule was sufficiently opacified to cause an objective decrease in best corrected visual acuity. None of the patients had a history of glaucoma or an IOP greater than $21 \mathrm{~mm} \mathrm{Hg}$ before treatment. Patients in whom pre-existing or current uveitis was present were excluded from the series. Informed consent was obtained from all the patients.

Just before inclusion in the study, each patient underwent ophthalmic assessment of both eyes; it included best corrected Snellen visual acuity, biomicroscopy, and applanation tonometry (baseline IOP). One hour before laser capsulotomy patients received orally either $125 \mathrm{mg}$ of acetazolamide sodium (28 patients) or placebo (26 patients) in a randomised, double-masked fashion. IOPs were measured before capsulotomy, and at 1,3 , and 24 hours after capsulotomy.

All posterior capsulotomies were performed by one of the authors (IDL), after topical anaesthesia with one drop of $0.5 \%$ proparacaine hydrochloride. A Peyman wide field YAG laser contact lens (OPY-1.25) was used in each case. Before capsulotomy the eyes of all patients were dilated with one drop of a mixture of $5 \%$ phenylephrine and $1 \%$ tropicamide. We used a Q-switched Nd-YAG laser (Pegasus 3002, Rodenstock) with the Nd-YAG laser beam retrofocused approximately $0.3 \mathrm{~mm}$ behind the helium-neon beam focused on the capsule. A single application technique was used and the burst mode was not employed. Our intention was to create a 3-4 mm diameter opening in the centre of the opacified capsule using the least amount of total laser energy.

After the capsulotomy, all eyes received one drop of $0.1 \%$ dexamethasone sodium phosphate three times daily for 3 days. No additional medical therapy was given to any patient for a period of 24 hours, unless the measured IOP was greater than $35 \mathrm{~mm} \mathrm{Hg}$. If the IOP exceeded $35 \mathrm{~mm} \mathrm{Hg}$, the patient was treated with one drop $0.5 \%$ timolol maleate twice daily and $250 \mathrm{mg}$ of oral acetazolamide four times daily. The patient was then observed until the IOP decreased to below $25 \mathrm{~mm} \mathrm{Hg}$.

Numerical data were recorded as mean (SD). Statistical significance for data comparison between patient groups was analysed using analysis of variance or $\chi^{2}$ analysis; $p$ values of less than 0.01 were considered significant. 
Results

Fifty four patients entered the study. Three patients treated with placebo were removed from the study because of very high IOP $(>35 \mathrm{~mm}$ $\mathrm{Hg}$ ). Two other patients of the same group and one treated with acetazolamide were lost to the 24 hour follow-up examination and were not included in the 24 hour IOP measurements.

There was no statistically significant difference between the two groups of patients with regard to sex, age, IOP before prophylactic treatment, and time interval from cataract surgery to posterior capsulotomy (Table 1). Additionally, there was no statistically significant difference between these groups of patients with regard to mean laser energy per pulse, number of pulses, or total laser energy used for capsulotomy per patient (Table 2). Just before capsulotomy the mean IOP of the acetazolamide group presented a slight decrease because of the earlier use of acetazolamide.

During the first 3 hours following capsulotomy, we noticed a mean IOP elevation in the placebo group which ranged from 5.8 to $6.1 \mathrm{~mm}$ $\mathrm{Hg}$ above baseline IOP. However, the mean IOP elevation in the acetazolamide group ranged from 0.7 to $1.1 \mathrm{~mm} \mathrm{Hg}(\mathrm{p}<0.001)$ (Table 3). Twenty four hours following capsulotomy there was no statistically significant difference in the mean IOP elevation between the two groups of patients (Table 3 ).

Within the first 3 hours following laser treatment, 16 of 26 eyes $(61 \cdot 5 \%)$ of the placebo group had an IOP elevation greater than $5 \mathrm{~mm} \mathrm{Hg}$ compared with only four of 28 eyes $(14 \cdot 3 \%)$ of the acetazolamide group $(\mathrm{p}<0.001)$ (Table 4). At the same time, eight of the 26 eyes $(30.8 \%)$ of the placebo group developed an IOP rise greater than $10 \mathrm{~mm} \mathrm{Hg}$. However, none of the eyes of the acetazolamide group developed such a high IOP rise $(\mathrm{p}<0.001)$ (Table 4$)$.

None of the eyes of the acetazolamide group

Table 1 Patient characteristics

\begin{tabular}{|c|c|c|c|}
\hline & $\begin{array}{l}\text { Acetazolamide } \\
(n=28)\end{array}$ & $\begin{array}{l}\text { Placebo } \\
(n=26)\end{array}$ & p Value \\
\hline \multicolumn{4}{|l|}{ Sex } \\
\hline $\begin{array}{l}\text { Female } \\
\text { Male }\end{array}$ & $\begin{array}{l}16(57 \cdot 1 \%) \\
12(42 \cdot 9 \%)\end{array}$ & $\begin{array}{l}15(57 \cdot 7 \%) \\
11(42 \cdot 3 \%)\end{array}$ & NS \\
\hline & & & \\
\hline $\begin{array}{l}\text { Mean (SD) } \\
\text { Range }\end{array}$ & $\begin{array}{l}69(8 \cdot 6) \\
48-85\end{array}$ & $\begin{array}{l}67 \cdot 1(7 \cdot 2) \\
50-83\end{array}$ & NS \\
\hline \multicolumn{4}{|l|}{ Time (months) } \\
\hline $\begin{array}{l}\text { Mean (SD) } \\
\text { Range }\end{array}$ & $\begin{array}{c}13(6 \cdot 1) \\
3-26\end{array}$ & $\begin{array}{c}11 \cdot 8(6 \cdot 7) \\
4-27\end{array}$ & NS \\
\hline \multicolumn{4}{|l|}{$\mathrm{IOP}(\mathrm{mm} \mathrm{Hg})+$} \\
\hline $\begin{array}{l}\text { Mean (SD) } \\
\text { Range }\end{array}$ & $\begin{array}{l}15 \cdot 4(3) \\
10-21\end{array}$ & $\begin{array}{l}16 \cdot 2(2 \cdot 7) \\
11-20\end{array}$ & NS \\
\hline \multicolumn{4}{|c|}{$\begin{array}{l}\text { NS=not significant. } \\
\star \text { IInterval from cataract surgery. } \nmid \text { Before prophylactic treatment. }\end{array}$} \\
\hline \multicolumn{4}{|l|}{ Table 2} \\
\hline & $\begin{array}{l}\text { Acetazolamide } \\
(n=28)\end{array}$ & $\begin{array}{l}\text { Placebo } \\
(n=26)\end{array}$ & p Value \\
\hline \multicolumn{4}{|c|}{ Energy/pulse (mJ/pulse) } \\
\hline Mean (SD) & $1.9(0.5)$ & $1 \cdot 8(0 \cdot 6)$ & NS \\
\hline $\begin{array}{l}\text { Range } \\
\text { No of pulses }\end{array}$ & $1 \cdot 2-3 \cdot 2$ & $1 \cdot 0-3 \cdot 2$ & ivo \\
\hline $\begin{array}{l}\text { Mean (SD) } \\
\text { Range }\end{array}$ & $\begin{array}{c}34(18) \\
4-98\end{array}$ & $\begin{array}{c}37(20) \\
5-76\end{array}$ & NS \\
\hline \multicolumn{4}{|c|}{$\begin{array}{l}\text { Kange } \\
\text { Total energy/patient (mJ/patient) }\end{array}$} \\
\hline $\begin{array}{l}\text { Mean (SD) } \\
\text { Range }\end{array}$ & $\begin{array}{c}63(37 \cdot 2) \\
6.4-176 \cdot 4\end{array}$ & $\begin{array}{l}62 \cdot 4(36 \cdot 6) \\
13-182 \cdot 4\end{array}$ & NS \\
\hline
\end{tabular}

NS $=$ not significant
Table 3 Mean $(S D)$ change in IOP from baseline

\begin{tabular}{llllllll}
\hline & \multicolumn{2}{l}{ Acetazolamide } & & \multicolumn{2}{l}{ Placebo } & \\
\cline { 2 - 3 } Time (hours) & $n$ & Mean (SD) & & $n$ & Mean $(S D)$ & p Value \\
\hline 1 & 28 & $0 \cdot 7(2 \cdot 8)$ & & 26 & $5 \cdot 8(5 \cdot 5)$ & $<0.001$ \\
3 & 28 & $1 \cdot 1(2 \cdot 9)$. & & 25 & $6 \cdot 1(6 \cdot 3)$ & $<0.001$ \\
24 & 27 & $0 \cdot 2(1 \cdot 6)$ & & 21 & $1 \cdot 2(2 \cdot 1)$ & NS \\
\hline
\end{tabular}

NS= not significant. ${ }^{\star}$ After laser capsulotomy.

Table 4 Patients with IOP elevation $>5$ and $10 \mathrm{~mm} \mathrm{Hg}$ after laser capsulotomy

\begin{tabular}{llll}
\hline $\begin{array}{l}\text { IOP elevation } \\
(\text { mm Hg) }\end{array}$ & $\begin{array}{l}\text { Acetazolamide (nio } \\
\text { of patients }(\%))\end{array}$ & $\begin{array}{l}\text { Placebo (no of } \\
\text { patients }(\%))\end{array}$ & p Value \\
\hline$>5$ & $4 / 28(14 \cdot 3)$ & $16 / 26(61 \cdot 5)$ & $<0 \cdot 001$ \\
$>10$ & $0 / 28(0)$ & $8 / 26(30 \cdot 8)$ & $<0.01$ \\
\hline
\end{tabular}

developed an IOP greater than $25 \mathrm{~mm} \mathrm{Hg}$ while nine $(34.6 \%)$ of the eyes of the placebo group developed an IOP of this level. Furthermore, three eyes $(10.7 \%)$ of the placebo group developed an IOP greater than $35 \mathrm{~mm} \mathrm{Hg}$ (one in the first and two in the third hour after laser treatment) and were treated with additional antiglaucoma medication. The IOPs dropped to less than $25 \mathrm{~mm} \mathrm{Hg}$ by the fourth hour after laser treatment.

There were no acetazolamide side effects reported in the treated patients.

\section{Discussion}

IOP elevation is the major complication of $\mathrm{Nd}$ YAG laser posterior capsulotomy. ${ }^{1-10}$ Because the IOP rise generally reaches its peak during the first 3 hours after laser treatment, ${ }^{5910}$ under ideal circumstances any drug used to prevent this complication must reach its maximum effectiveness at the same time. Oral acetazolamide reaches near maximum plasma levels 1 hour after administration. The maximum IOP reduction is attained within 2 hours and is maintained for 5 to 6 hours after administration. ${ }^{21} 22$ Thus, a single dose of oral acetazolamide given 1 hour before Nd-YAG laser posterior capsulotomy should produce maximum hypotensive effect, to coincide with the time of potential maximum IOP elevation.

Prophylactic treatment to prevent a complication is worthwhile when this complication is commonly anticipated, when it has serious sequelae and when such a prophylactic treatment is safe and effective. The results of our study showed that the prophylactic administration of $125 \mathrm{mg}$ of oral acetazolamide to prevent IOP elevation following routine Nd-YAG laser posterior capsulotomy meets the above mentioned criteria.

Eyes with pre-existing glaucoma were excluded from our study. Therefore, we cannot report if pretreatment with acetazolamide would be effective in preventing IOP elevation following Nd-YAG laser posterior capsulotomy in these high risk eyes. However, we must assume that, especially in glaucomatous eyes which are already under a maximal reduction of aqueous production because of treatment with $\beta$-blockers and acetazolamide, the additional prophylactic use of acetazolamide would probably be ineffective. 
Several studies ${ }^{13-20}$ have shown that the prophylactic use of other antiglaucoma medication such as apraclonidine, levobunolol, timolol, and pilocarpine is also effective in preventing or reducing the IOP rise after Nd-YAG laser capsulotomy. As some of this medication is not readily available worldwide and/or cannot be administered to certain patients because of contraindications, we believe that a widely available drug (such as oral acetazolamide), given in a very low dose, is an important alternative therapy in the prevention of vision-threatening IOP elevation in patients undergoing Nd-YAG laser posterior capsulotomy.

1 Terry AC, Stark WJ, Maumenee AE, Fagadau W. Neodymium YAG laser for posterior capsulotomy. $A m \dot{f}$ Ophthalmol 1983; 96: 716-20.

2 Channell MM, Beckman H. Intraocular pressure changes after neodymium-YAG laser posterior capsulotomy. Arch Ophthalmol 1984; 102: 1024-6.

3 Parker WT, Clorfeine GS, Stoclin RD. Marked intraocular pressure rise following Nd-YAG laser capsulotomy. pressure rise following Nd-

4 Vine AK. Ocular hypertension following Nd:YAG laser capsulotomy: a potentially blinding complication. Ophthalmic Surg $1984 ; 15: 283-4$.

5 Flohr MJ, Robin AL, Kelley JS. Early complications following $Q$-switched neodymium-YAG laser capsulotomy. Ophthalmology 1985; 92: 360-3

6 Kraf MC, Sanders DR, Lieberman HL. Intraocular pressure and the corneal endothelium after neodymium-YAG laser posterior capsulotomy. Relative effects of aphakia and pseudophakia. Arch Ophthalmol 1985; 103: 511-4.

7 Nirankari VS, Richards RD. Complications associated with the use of the neodymium: YAG laser. Ophthalmology 1985; 92: 1371-5.

8 Slomovic AR, Parrish RK. Acute elevations of intraocular pressure following Nd:YAG laser posterior capsulotomy. Ophthalmology 1985; 92: 973-6.

9 Stark WJ, Worhten D, Holladay JT, Murray G. Neodymium:
YAG lasers. An FDA report. Ophthalmology 1985; 92: 20912.

10 Richter CU, Arzeno G, Pappas HR, Steinert RF, Puliafito C, Epstein DL. Intraocular pressure elevation following Nd: YAG laser posterior capsulotomy. Ophthalmology 1985; 92: 636-40.

11 Kurata F, Krupin T, Sinclair S, Kapp L. Progressive glaucomatous visual field loss after neodymium-YAG lase capsulotomy. Am $\mathcal{F}$ Ophthalmol 1984; 98: 632-4.

12 Blackwell C, Hirst LW, Kinnas SJ. Neodymium-YAG laser capsulotomy and potential blindness. Am $\mathcal{F}$ Ophthalmol 1984; 98: 521-2.

13 Brown RH, Stewart RH, Lynch MG, Crandall AS, Mandell AI, Wilensky JT, et al. ALO 2145 reduces the intraocular pressure elevation after anterior segment laser surgery. Ophthalmology 1988; 95: 378-84.

14 Pollack IP, Brown RH, Crandall AS, Robin AL, Stewart RH, White GL. Prevention of the rise in intraocular pressure following neodymium-YAG posterior capsulotomy using topical 1\% apraclonidine. Arch Ophthalmol 1988; 106: 754-7.

15 Silverstone DE, Brint SF, Olander KW, Taylor RB, McCarty GR, de Faller JM, et al. Prophylactic use of apraclonidine for intraocular pressure increase after Nd:YAG capsulotomies. Am F Ophthalmol 1992; 113: 401-5.

16 Silverstone DE, Novack GD, Kelley EP, Chen KS Prophylactic treatment of intraocular pressure elevations after neodymium:YAG laser posterior capsulotomies and extracapsular cataract extractions with levobunolol. Ophthalmology 1988; 95: 713-8.

17 Stilma JS, Boen-Tan TN. Timolol and intra-ocular pressure elevation following neodymium:YAG laser surgery. Doc Ophthalmol 1986; 61: 233-9.

18 Migliori ME, Beckman H, Channell MM. Intraocular pressure changes after neodymium-YAG laser capsulotomy in sure changes after neodymium-YAG laser capsulotomy in eyes p

19 Richter CU, Arzeno G, Pappas HR, Arrigg CA, Wasson P, Steinert RF. Prevention of intraocular pressure elevation following neodymium-YAG laser posterior capsulotomy. Arch Ophthalmol 1985; 103: 912-5.

20 Brown SVL, Thomas JV, Belcher DC, Simmons RJ. Effect of pilocarpine in treatment of intraocular pressure elevation following neodymium:YAG laser posterior capsulotomy. Ophthalmology 1985; 92: 354-9.

21 Freiedland BR, Mallonee J, Anderson DR. Short-term dose response characteristics of acetazolamide in man. Arch Ophthalmol 1977; 95: 1809-12.

22 Ellis PP, Price PK, Kelmenson R, Rendi MA. Effectiveness of generic acetazolamide. Arch Ophthalmol 1982; 100: 1920-2. 